\title{
Sınıf Öğretmenlerinin Perspektifinden Değerler ve Değerler Eğitimi Uygulamalarının Değerlendirilmesi
}

\author{
The Assessment of Values Education Activities According to the Primary School \\ Teachers' Opinions
}

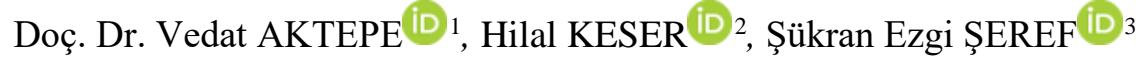

\begin{abstract}
$\ddot{O} \mathbf{z}$
$\mathrm{Bu}$ araştırmanın amacı, değerler eğitimi etkinliklerini sınıf öğretmenlerinin görüşleri kapsamında incelemektir. Sınıf öğretmenlerinin görüşlerine göre mevcut durumun ortaya konması bakımından durum çalışması yöntemine yer verilmiştir. Araştırmada veri toplama aracı olarak görüşme tekniği kullanılmıştır. Araştırma verileri uzman görüşü alınarak hazırlanan yapılandırılmış görüşme formu kullanılarak toplanmıştır. Veriler analiz edilirken içerik analizinden yararlanılmıştır. Araştırmaya Nevşehir ve Kayseri illerine bağlı okullarda görev yapan toplam 25 sınıf öğretmeni katılmıştır. Araştırmanın sonucunda öğretmenlerin birçoğu, değerler eğitiminin amacının karakter gelişimini sağlamak olduğunu belirtmişlerdir. Öğretmenler değerler eğitiminde en fazla örnek olay, drama, film, resim, öyküden yararlandıklarını ifade etmişlerdir. Öğretmenler değerler eğitiminde karşılaştığı güçlükler olarak, çocukların değer eğitiminin çoğu zaman adını bilmediklerini ve başka da bir güçlükle karşılaşmadıklarını dile getirmişlerdir. Yine öğretmenler örtük olarak verilen değerlerin, eğitim programlarında daha çok kazanımlarla birlikte verildiğini söylemişlerdir. Araştırmanın sonucunda, öğretmenlerin birden fazla değer eğitimi yaklaşım, yöntem ve tekniğini kullandıkları görülmüştür. Öğretmenler kullanım sıklığına göre; drama, soru-cevap, hikaye yazma, film izleme, atasözleri ve deyim, eğitici oyunlar, altı şapka tekniği, bulmaca ve bilmece, kavram haritası, poster, beyin firtınası olarak sıralamışlardır. Ayrıca öğretmenlerin çoğu "ayın değeri” etkinliklerini yeterli bulmamaktadır. Öğretmenler, değerler eğitiminin "zorunlu ders" kapsamında okutulması yönünde görüş bildirmişlerdir.
\end{abstract}

Anahtar Kelimeler: Değer, değerler eğitimi uygulamaları, sınıf öğretmeni, değerlendirme

Makale Türü: Araştırma

\begin{abstract}
The purpose of the current study is to analyse values education activities according to primary school teachers' opinion. In order to reveal the current situation according to views of primary school teachers, case study method was included. The interview technique was used as a data collection tool in the research. Research data were collected through structured interview forms which were prepared upon asking the opinions of experts in the field. Content analysis method was used during the course of data analysis. 25 teachers, working in schools either in Kayseri or in Nevsehir provinces of Turkey, took part in the study. As a result of the research teachers have stated that the purpose of values education is to provide personal development. They said that they mostly benefited from case studies, drama, films, pictures and stories during values education. Teachers state that the only difficulty that they meet during values education is children who are not familiar with the term. Moreover, teachers stated that values taught tacitly are mostly conveyed with learning outcomes in curriculum. At the end of the study teacherswere seen to use more than one approach, method and technique of values education. According to frequency of use, following methods were stated to be used by teachers; drama, question-answer, storywriting, watching films, idioms and proverbs, educational games, six thinking hats method, puzzles and
\end{abstract}

\footnotetext{
${ }^{1}$ Nevşehir Hacı Bektaş Veli Üniversitesi, Eğitim Fakültesi, vedataktepe@nevsehir.edu.tr.

${ }^{2}$ Nevşehir Hacı Bektaş Veli Üniversitesi, Sosyal Bilimler Enstitüsü, hilalhcslymngl@hotmail.com.

${ }^{3}$ Nevşehir Hacı Bektaş Veli Üniversitesi, Sosyal Bilimler Enstitüsü, ezgiseref38@gmail.com.
}

Atıf için (to cite): Aktepe, V., Keser, H. ve Şeref, Ş. E. (2020). Sınıf öğretmenlerinin perspektifinden değerler ve değerler eğitimi uygulamalarının değerlendirilmesi. Afyon Kocatepe Üniversitesi Sosyal Bilimler Dergisi, 22(4), 897-918. 
riddles, concept maps and brainstorming. Moreover most of the teachers find "Value of Month" events insufficient. A consensus was reached on teaching values education as an "obligatory course" by teachers.

Keywords: Values, values education activities, primary school teacher, assessment

Paper Type: Research

\section{Giriş}

Değerler eğitimi, Birleşmiş Milletler Eğitim, Bilim ve Kültür Örgütü (UNESCO) tarafından desteklenmektedir. $\mathrm{Bu}$ anlamda UNICEF sponsorluğunda sürdürülen Yaşayan Değerler Eğitimi Programı (YDEP) amacı, dünyanın dört bir yanında değerler eğitimini yaygınlaştırmaktır. Nitekim bu program dünya genelinde eğitmenler arasında ortaklıktan doğan, kâr amacı gütmeyen bir programdır. Dünyanın dört bir yanındaki 20 eğitimcinin Ağustos 1996'da Newyork'ta UNICEF'in Genel Merkezi'nde çocukların ihtiyaçlarını, onların değerlerle olan çalışma tecrübelerini ve öğrencileri hayata daha iyi hazırlamak ve değerleri nasıl öğreteceklerini tartışmak için bir araya gelmişlerdir (Tillman, 2014, s.33). Türkiye'de değerler eğitiminin tarihçesine bakacak olursak; eğitim sisteminin düzenlenmesi cumhuriyetin ilanından sonra Tehvid-i Tedrisat Kanunu ile gerçekleşmiştir. 1924 İlkokul programında öğrencilere insani ve toplumsal değerlerin de kazandırılması gerektiği belirtilmektedir. Bu bakımdan "Muhasabat-1 Ahlakiye" ve "Malumat-1 Vataniyye (Yurt Bilgisi)" dersleri son derece önemlidir. "Muhasabat-1 Ahlakiye" ve "Malumat-1 Vataniyye (Yurt Bilgisi)" derslerinin amac1 Türkiye Cumhuriyeti vatandaşının sahip olduğu hak ve görevleri tanımak; ahlak hakikatlerini telkin etmek, ulusal ve insani görevlerini yerine getirecek bireyler yetiştirmektir (Uzunkol, 2019, s. 265).

Alanyazına bakıldığında değerler eğitiminin farklı şekillerde tanımlandığı görülmektedir. Değerler eğitimi; "toplumların büyük bir çoğunluğu tarafından kabul görmüş ve korunmaya çalışılan temel ahlaki ilkelere dayanan ortak amaçlar, inanışlar, standartlar, yargılar ve kurallardır." (Çınar, 2019, s.6). Ulusal yazında olduğu gibi uluslararası yazın incelendiğinde de farklı değer sınıflandırmalarının yapıldığı görülmektedir. Uluslararası yazında en çok bilinen ve kullanılan Rokeach ve Spranger'in değer sınıflandırmalarıdır. Buna göre Spranger değerleri (Akbaş, 2004, s.56-57):

- Bilimsel değer: Gerçeği araştırmaya, "bilgiye, muhakemeye ve eleştirel düşünceye önem verir."

- Ekonomik değer: Faydalı ve pratik olana önem verip "ekonomik değerlerin hayatta önemsenmesi gerektiğini belirtir."

- Estetik değer: Simetri, uyum ve forma önem verip "sanatın toplum için bir zorunluluk olduğunu düşünür."

- Sosyal değer: Başkalarını sevme, başkalarına yardım etme ve bencil olmama esastır. En yüksek değer insan sevgisidir.

- Politik değer: Güç, yetkinlik, liderlik vb. değerleri kapsar.

- Dini değer: Evreni bir bütün olarak kavrar ve "kendisini onun bütünlüğüne bağlar. Dini uğruna dünyevi hazları feda eder.” şeklinde sınıflandırmıştır.

Rokeach' in (1973) değer sinıflandırması şu şekildedir (Akt. Çelikkaya, 2019, s.73):

- Gaye (amaç) değerler: Aile güvenliği, barış içinde bir dünya, başarma hissi, bilgelik/hikmet, eşitlik, gerçek dostluk, gerçek sevgi, güzellikler dünyası, heyecanlı bir hayat, iç huzuru, kurtuluş, mutluluk, öz saygı, özgürlük, rahat bir yaşam, sosyal tanınma, ulusal güvenlik, zevk. 
- Vasıta (araç) değerler: Affedici, bağımsızlık, cesaretli, dürüst, entelektüel, hayal gücü kuvvetli, hırslı/istekli, itaatkâr, kabiliyetli, kibar, mantıklı, neşeli, öz kontrol, sevgi dolu/sevecen, sorumlu, temiz, ufku geniş olma, yardımsever.

Güngör'ün değer sınıflandırması da (1998) şu şekildedir:

1. Dini Değerler: Öbür dünyayı kazanma, güzelliklerle dolu bir dünya,

2. Ahlaki Değerler: Yalansız bir dünya, huzurlu vicdan,

3. Sosyal Değerler: Gerçek dostluk, insanlara yardım,

4. Siyasi Değerler: Eşitliğin sağlanması, hürriyet için mücadele,

5. Teorik- Bilimsel Değerler: Gerçeklerin bilinmesi, cahillikten arınmış bir dünya,

6. Estetik Değerler: Her şeyin ölçülü ve ahenkli olması, güzelliklerle dolu dünya,

7. Ekonomik Değerler: Ekonomik bağımsızlık, konforlu hayat.

Araştırmada, okulda yapılan değerler eğitiminin amaçları incelenirken Aktepe ve Gündüz (2018) tarafından yapılan değer sınıflandırması göz önüne alınmıştır. Bu bağlamda Aktepe ve Gündüz $(2018$, s.78) tarafindan yapılan değer sınıflandırmasına göre:

1. Milli değerler: Vatanseverlik, bağımsızlık, birlik ve kültürünü yaşatmak.

2. Dini değerler: Allaha inanmak, iffetli olmak, sadelik, tutumluluk, sabır, aileye bağl1lı, cömertlik, alçakgönüllülük ve güvenilirlik.

3. Evrensel değerler: Barış, mutluluk, temizlik, sağlık, sorumluluk, estetik, dürüstlük, özgürlük, sayg1, sevgi, adalet ve bilimsellik.

4. İnsani değerler: Anlayış, iyilik, duyarlılık, yardımseverlik, empati, fedakârlık, paylaşma, merhamet, hoşgörü ve vefalılık.

5. Bireysel değerler: Öz saygı, öz güven, öz denetim, açık fikirlilik ve gayretli olmak

6. Toplumsal değerler: Misafirperverlik, dayanışma, iş birliği ve çalışkanlık.

Değerlerin öğretiminde okullar önemli bir yere sahiptir. Bu bağlamda aile, toplum, çevre, sosyal iletişim şekli vb. ile birlikte öğretmenlerin değerler öğretimindeki rolü büyüktür. Ayrıca okulda yürütülen sosyal faaliyetlerde aile ile iş birliği konusu da önemlidir. Nitekim yaşamamızın bütününde yer alan değerlerin çocuklarımızın yarınlara hazırlanmasında okulların rolü yadsınamaz. Bu da okullarda etkili bir değer eğitimini gerekli kılmaktadır (Yalar ve Yanpar Yelken, 2011, s.87). Okulların ve öğretmenlerin değerler eğitimindeki rolü 18. Milli Eğitim Şurası'nda da görülmektedir. Söz konusu şûrada “okulların, kendine özgü bir kimlik, hafıza, aidiyet duygusu ve güçlü okul kültürü geliştirebilmeleri için geniş katılımlı özel günler, haftalar gibi etkinlikler düzenlenerek ortak kültürel değerlerin güçlendirilmesi sağlanmalıdır" ve "güçlü okul kültürleri geliştirebilmek için okullara özgü logo, amblem, rozet, marş, kahraman, hikâye, gazete, tablo, slogan vb. semboller oluşturularak okulların ortak kültürel değerlerin güçlendirmesi sağlanmalıdır” (MEB, 2010) şeklinde ifade edilmektedir.

Sınıf öğretmeni değerlerin öğrencilere kazandırılmasında kilit öneme sahiptir. Öğretmen, öğrencilerinin yerine kendini koyabilir ve onlara saygılı davranabilirse rol model olabilir. Kaldı ki temel eğitim döneminde öğrenciler öğretmenlerini taklit ederek öğrenirler. İlkokul çağındaki öğrenciler somut işlemler dönemindedir. Soyut kavramlar olan değerlerin bu çağda öğrencilere kazandırılabilmesi için etkinlikler yapılmalı ve yaparak yaşayarak öğrenme temelinde değerler somut hale getirilmelidir. Bu bağlamda her öğretmenin birer değer eğitimcisi olması beklenmektedir. Aktepe (2015, s.186) değer ve karakter eğitimcisi etkinlikleri planlarken; anlatım, telkin ve öğüt vermenin ötesine geçebilmeli ve uygun strateji, yöntem ve teknikleri kullanabilmelidir. Değer eğitimcisi etkinlikleri düzenlerken; örnek olay, empati, 
drama, hikâyeleştirme, problem çözme, görüşme, değer açılama, ahlaki muhakeme, değer analizi gibi strateji, yöntem ve tekniklerden faydalanabilmelidir.

Etkinlik, insanın çevresiyle arasındaki ilişkileri düzenleyen her türlü eylemi; bir canlının iç veya dış uyaranların etkisiyle giriştiği çalışma durumu; etkin olma durumu, faaliyet, aktivite (TDK, 2011, s.830). Değerler eğitiminin okullarda etkinlik yoluyla verilmesi yönünde pek çok araştırmaya (Dilmaç, 2012, Külünkoğlu, 2018; Ulusoy, 2007, Uzun ve Köse, 2017) rastlanmıştır: Bu bağlamda Ulusoy (2007)'a göre değerler, sınıflarda okulun ve toplumun gerçekleştirdiği etkinlikler aracılığıyla öğretilir. Dilmaç (2012) grupla yapılan etkinliklerin tüm insani değerleri geliştirebileceğini belirtmiştir. Piyesin, sanatın, zanaatın, tartışmaların, bilmecelerin vb. etkinliklerin kullanımı bunu sağlayabilir. Külünkoğlu (2018) Eğitim-öğretim yılının herhangi bir haftası "Değer Eğitimi Haftası" olarak ilan edilmesi gerektiğini, bu haftada üniversitelerde ve tüm okullarda değer eğitimi konferansları ve sempozyumları yapılmalı, liselerde değer eğitimi üzerine şiir, masal, kompozisyon, resim, fotoğraf, slogan yarışmaları düzenlenmeli, sanatçı, siyasetçi, sporcu, iş adamı, bilim insanı gibi topluma rol model olabilecek insanlar değer eğiminin önemini anlatabilecek etkinliklerde bulunmalıdır. Uzun ve Köse (2017, s.315) ise öğretmenler tarafından değerler eğitimine ait içeriklere yer verilen etkinlik çeşitlerinin nedeni olarak; bu etkinliklerin kalıcı öğrenmeyi sağlaması, soyut kavramları verebilmeye uygun olması, yöntem ve materyale ulaşmanın kolay olması nedenlerinin olduğu sonucuna ulaşılmıştır.

Geçmişten günümüze toplumların sosyal ve kültürel yapılarında değişimlerin olması, bilgi ve teknolojideki hızlı gelişmeler, bireylerin sosyalleşmelerinde olumsuz etkileri olmuş; bireyci ve bencil insanlar artmış, empatiden yoksun, asosyal bir toplum yapısı ortaya çıkarmıştır denebilir. Nitekim değerler eğitimi okullarda bu gibi nedenlerden dolayı önemsenmektedir. Araştırma öğrencilerin değer kazanımlarını edinmelerinde etkinliklerin değerlendirilmesi konusu, gelecek nesiller adına toplumsal bilinç oluşturma bakımından da önemli görülmektedir. Alan yazına bakıldığında konu ile ilgili yapılmış farklı araştırmalar (Gür, Koçak, Şirin, Şafak ve Demircan, 2015; Yalar ve Yanpar Yelken 2011) bulunmaktadır. Gür ve diğerleri (2015) ise yaptıkları araştırmada değerlerin soyut bir konu olmasından dolayı yaş gruplarına uyarlamada sıkıntı yaşadıklarını ifade etmişlerdir. Yalar ve Yanpar Yelken (2011) ise araştırmalarında ailelerle iş birliği ve ailelerin eğitilerek sürece katılmasının değer eğitimi için önemli olduğu sonucuna ulaşmışlardır.

\section{Yöntem}

$\mathrm{Bu}$ araştırmada amaç, sınıf öğretmenlerinin değerler eğitimine ilişkin görüşlerini ortaya koymaktır. Çalışma nitel araştırma yöntemlerinden durum çalışması desenine göre hazırlanmış ve uygulanmıştır. Nitel araştırmalar; ilişkilerin, etkinliklerin, durumların ya da materyallerin niteliğinin incelendiği çalışmalardır. Nitel araştırmalarda gözlem, görüşme, doküman analizi gibi veri toplama teknikleri kullanılır (Büyüköztürk, Çakmak, Akgün, Çakmak, Karadeniz ve Demirel, 2019, s.20). Araştırmada ise mevcut durumu ortaya koymak için görüşme tekniği kullanılmıştır.

McMillan (2000)'a göre durum çalışmalarının bir ya da daha fazla olayın, ortamın, programın, sosyal grubun ya da diğer birbirine bağlı sistemlerin derinlemesine incelendiği yöntem olarak tanımlanmaktadır (Büyüköztürk vd., 2019, s.23). Alanyazın da görüşme tekniği ise en az iki kişi arasında sözlü olarak yapılan bir iletişim sürecidir olarak tanımlanmaktadır. Görüşme süreci araştırma da cevabı aranan sorular kapsamında görüşme yapılan kişilerden toplanan verilerle yapılmaktadır. Görüşme yapmanın en büyük faydalarından biri araştırılan konu veya cevabına ulaşılmak istenen sorular hakkında derinlemesine bilgi sağlamasıdır (Büyüköztürk vd,, 2019, s.158).

$\mathrm{Bu}$ bağlamda, öğrencilerin temel eğitim düzeyinde değerler eğitimini kazanmasının önemi dikkate alındığında sınıf öğretmenlerinin değerler eğitimine ilişkin görüşleri alınmıştır. Nitekim araştırmanın amacı doğrultusunda değer eğitiminde sınıf öğretmenlerinin kullandıkları 
yaklaşım, yöntem ve teknikler, yapılan etkinlikler, ders bazında öğretim programdaki değerler incelenmiştir. Yine Milli Eğitim Bakanlığı [MEB] değerler eğitimi kapsamında ayın değeri etkinliklerinin değerlendirilmesi, verilen değerlerin öğretim programlarında ele alınıs durumu, değerler eğitimini zorlaştıran etmenler ve çözüm arayışları gibi konular sınıf öğretmenlerinin görüşlerine göre araştırılmıştır.

\subsection{Katılımcilar}

Araştırmada amaçlı örnekleme yöntemlerinden tipik durum örneklem yöntemi kullanılmıştır. Bu amaçla 2019-2020 eğitim öğretim yılında Kayseri ve Nevşehir ili Millî Eğitim Müdürlüğüne bağlı devlet okullardan tipik durum örneklemeyle belirlenen yirmi beş sınıf öğretmeni çalışma grubu olarak belirlenmiştir. Marshall \& Rossman'a göre (2014) tipik durum örnekleme, evreni temsil yeteneği olan ve temel özellikleri bakımından evrenden farklılaşmayan durumları ifade etmek için kullanılmaktadır (Akt. Baltacı, 2018, s.251). Tipik durum örneklemesi tipik, sıradan, normal veya ortalama durumları göstermek için kullanılmaktadır (Baltacı, 2018, s.251).

Tablo 1. Görüşme yapılan okullar ve öğretmen sayıları

\begin{tabular}{lc}
\hline Görüşülen okullar & Görüşmeye katılan öğretmen sayısı \\
\hline 1. Kayseri ili - Mustafa Çataloğlu İlkokulu & 10 \\
2. Nevşehir ili- Cumhuriyet İlkokulu & 5 \\
3. Nevşehir ili - Kurugöl 70. Yıl İlkokulu & 3 \\
4. Nevşehir ili -Ürgüp Türkan Diker İlkokulu & 3 \\
5. Nevşehir ili -Kaymaklı İlkokulu & 2 \\
6. Nevşehir ili -Tatlarin İlkokulu & 1 \\
7. Nevşehir75. Yıl İlkokulu & 1 \\
Toplam & $\mathbf{2 5}$ \\
\hline
\end{tabular}

\subsubsection{Veri Toplama Aracı}

$\mathrm{Bu}$ araştırmada veriler araştırmacı tarafından geliştirilen yapılandırılmış görüşme formu aracılığıyla toplanmıştır. Yapılandırılmış görüşmelerde araştırmacının önceden hazırlamış olduğu sorular vardır. Bu yol verilerin hızlı kodlanmasına, analizine, ölçüm kolaylığına ve araştırmanın kapsamıyla karşılaştırılmasına imkân verir. Bu yöntem yapılan anketin aksine görüşmeciye ihtiyaç duyulduğu anda kaynak kişinin sorularına cevap verme imkânı sağlar (Büyüköztürk vd., 2019, s.159). Ayrıca bu yöntem özel bir konuda derinlemesine soru sorma ve cevap eksik veya açık değilse tekrar soru sorarak durumu daha açıklayıcı hale getirip cevapları tamamlama firsatı vermesi açısından avantajlıdır. Araştırmacı önceden hazırladığ sorularla, görüşmeyi yapan kişiyi kısıtlar, farklı alanlara yönelmesine imkân vermez (Çepni, 2007). Araştırmanın yapı ve kapsam geçerliğini sağlamak için önce araştırılan konuyla ilgili kuramsal bilimin kavram ve olgularını araştırılmış ve ilgili literatür taranmıştır. Bu anlamda elde edilen verilere göre hazırlanan görüşme soruları, üniversitede sınıf öğretmenliği bölümü değerler eğitimi alanında uzman bir öğretim üyesinin görüşü alınarak düzenlenmiştir. Daha sonra hazırlanan görüşme sorularının dil geçerliğini sağlamak için üniversitede Türkçe eğitimi bölümünde alanında uzman bir öğretim üyesine inceletilmiş ve görüşme formunun son şekli elde edilmiştir. Netice olarak görüşme formu başlangıçta 12 sorudan oluşmakta iken, uzman görüşlerinden sonra 9 soruya düşürülmüş ve görüşme formuna son şekli verilmiştir. $\mathrm{Bu}$ bağlamda araştırmanın amacı doğrultusunda belirlenen aşağıdaki görüşme soruları sınıf öğretmenlerine yöneltilmiştir:

1. İlkokulda değerler eğitiminin amacı nedir?

2. Değerler eğitiminde ne tür etkinlikler yaparsınız?

3. Değerler eğitiminde karşılaştığınız güçlükler nelerdir? Çözüm önerileriniz nelerdir?

4. Değerler, ders öğretim programlarında nasıl ele alınmıştır? 
5. Değerler eğitiminde kullandığınız strateji, yöntem ve teknikler nelerdir?

6. Değerler eğitiminde kullandığınız değer eğitimi yaklaşımları nelerdir?

7. Değerler eğitiminde dersler bazında hangi değerleri hangi derslerde kazandırıyorsunuz?

8. MEB değerler eğitimi uygulamaları kapsamında ayın değeri etkinliklerini yeterli buluyor musunuz? Varsa önerileriniz nelerdir?

9. Değerler eğitiminin zorunlu veya seçmeli ders olarak okutulması konusunda ne düşünüyorsunuz?

\subsubsection{Verilerin Toplanmast ve Analizi}

Katılımcılarla yüz yüze yapılan görüşmeler yapılmadan önce, araştırma sürecine gönüllü olarak katılabileceği, görüşmelerin ses kayıt cihazına alınacağı ve yazarak belgelendirileceği, isimlerinin gizli tutulacağ gibi konularda bilgi verilmiş ve onayları alınmıştır. Görüşme verilerinin üzerinde herhangi bir değişiklik yapılmadan, verilerin dökümü yapılmış ve veriler bilgisayar ortamında yazılı şekle dönüştürülmüştür. Araştırma sonucunda elde edilen veriler, nitel araştırmalarda kullanılan veri analizi tekniklerinden içerik analizi kullanılarak değerlendirilmiştir. İçerik analizi, belirli kurallara dayalı kodlamalarla bir metnin bazı sözcüklerinin daha küçük içerik kategorileri ile özetlendiği sistematik, yinelenebilir bir tekniktir (Büyüköztürk vd. 2019, s.259). Ses kayıt cihazına alınan veriler dinlenilmiş, görüşme formundaki soruların yanıtları tek tek bilgisayar ortamında yazıya dökülmüşsür. İçerik analizi sonucunda veriler analiz edilmiş, kavramların benzer ve farklılıklarına göre temalar oluşturulmuş, temalar altında da kavramların frekans ve yüzdeleri alınmıştır. Araştırmaya katılan öğretmenlerin görüşleri alınırken ve incelenirken bir ile yirmi beş arasında (Ö-1, Ö-2, Ö$3, \ldots . .0 ̈-25)$ numaralandırılmıştır. Öğretmenlerin ifadeleri doğrudan verilmek suretiyle doğrudan alıntılar yapılmış veriler betimsel olarak da açıklanarak araştırma bulguları desteklenmiştir.

\section{Bulgular}

Değerler eğitimi etkinliklerine ilişkin sınıf öğretmenlerinin görüşleri doğrultusunda bulgulara aşağıda yer verilmiştir:

\section{1.İlkokulda değerler eğitiminin amacı nedir?}

Sınıf öğretmenlerinin verdikleri cevaplar doğrultusunda değerler eğitiminin amacı; karakter gelişimini sağlamak, öğrencinin topluma faydalı birey olması, toplumsal değerler, öğrenciyi hayata hazırlamak gibi farklı başlıklar altında toplanmıştır.

Tablo 2. Sınıf öğretmenlerinin görüşlerine göre ilkokulda değerler eğitiminin amaçları

\begin{tabular}{|lcc|}
\hline Milli Değerler & f & $\mathbf{\%}$ \\
\hline 1. Kendi kültürünü tanımak sahip çıkmak. & 2 & 8 \\
2. Vatana millete faydalı birey olmak. & 2 & 8 \\
3. Unutulan değerleri geliştirmek. & 1 & 4 \\
4. Türk toplumunda birlik ve beraberliği sağlamak. & 1 & 4 \\
5. Ortak noktada buluşup birçok değeri kaybetmemek. & 1 & 4 \\
Toplam & $\mathbf{7}$ & $\mathbf{2 8}$ \\
\hline Dini Değerler & $\mathbf{f}$ & $\mathbf{\%}$ \\
\hline 1. Kültüre ve inanca göre yaşamak. & 1 & 4 \\
Toplam & $\mathbf{1}$ & $\mathbf{4}$ \\
\hline Evrensel Değerler & $\mathbf{f}$ & $\mathbf{\%}$ \\
\hline 1. Vicdanlı özgür bireyler yetiştirmek. & 2 & 8 \\
Toplam & $\mathbf{2}$ & $\mathbf{8}$ \\
\hline İnsani Değerler & $\mathbf{f}$ & $\mathbf{\%}$ \\
\hline 1. Doğruya yönlendirmek. & 2 & 8 \\
2. İyi ahlaklı birey yetiştirmek. & 2 & 8 \\
Toplam & $\mathbf{4}$ & $\mathbf{1 6}$ \\
\hline
\end{tabular}




\begin{tabular}{|lcc|}
\hline Bireysel Değerler & f & $\mathbf{\%}$ \\
\hline 1. Kişilik sahibi bireyler yetiştirmek. & 4 & 16 \\
2.Karakter sahibi birey yetiştirmek. & 4 & 16 \\
3. Hayata hazırlamak. & 2 & 8 \\
4. Doğru karakter oluşturmak. & 1 & 4 \\
5. Doğru davranış kazandırmak. & 1 & 4 \\
Toplam & $\mathbf{1 2}$ & $\mathbf{4 8}$ \\
\hline Toplumsal Değerler & $\mathbf{f}$ & $\mathbf{\%}$ \\
\hline 1.Topluma uyum sağlamak. & 4 & 16 \\
2.Sosyalleşmeyi sağlamak. & 1 & 4 \\
3. Birlikte hareket etme duygusu kazandırmak. & 1 & 4 \\
4. Toplumda suç oranını düşürmek. & 1 & 4 \\
Toplam & $\mathbf{7}$ & $\mathbf{2 8}$ \\
\hline
\end{tabular}

Tablo 2 incelendiğinde, sınıf öğretmenlerinin görüşlerine göre ilkokulda değerler eğitiminin amaçları Aktepe ve Gündüz (2018) sınıflandırmasına göre ele alınmıştır. İlkokulda değerler eğitiminin amacı öncelikli olarak sırasıyla bireysel değerler (\%48), toplumsal değerler $(\% 28)$, milli değerler (\%28), insani değerler (\%16), evrensel değerler (\%8), dini değerlerdir (\%4). Sınıf öğretmenlerinin cevaplarının en fazla "bireysel değerler" (\%48) başlığında toplandığı görülmektedir.

Bu bağlamda öğretmenler, ilkokulda değer eğitiminin amaçlarının "bireysel değerler" kapsamında kişilik sahibi bireyler yetiştirmek (\%16), karakter sahibi birey yetiştirmek (\%16), hayata hazırlamak (\%8), doğru karakter oluşturmak (\%4), doğru davranış kazandırmak (\%4) olduğunu ifade etmişlerdir. İlkokulda değerler eğitiminin amacının "toplumsal değerler" (\%28) ve "milli değerleri” (\%28) kazandırmak ise ikinci önemli değerlerdir. Bu bağlamda öğretmenler, ilkokulda değer eğitiminin amaçlarının "toplumsal değerler" kapsamında topluma uyum sağlamak (\%16), sosyalleşmeyi sağlamak (\%4), birlikte hareket etme duygusu kazandırmak (\%4) ve toplumda suç oranını düşürmek (\%4), şeklinde ifade etmişlerdir. Milli değerler kapsamında kendi kültürünü tanımak sahip çıkmak (\%8), vatana millete faydalı birey olmak (\%8), unutulan değerleri geliştirmek (\%4), Türk toplumunda birlik ve beraberliği sağlamak (\%4) ve ortak noktada buluşup birçok değeri kaybetmemek (\%4), şeklinde ifade etmişlerdir.

Öğretmenler ilkokulda değer eğitiminin amaçlarının "insani değerler" (\%16) kapsamında doğruya yönlendirmek (\%8) ve İyi ahlaklı birey yetiştirmek (\%8) şeklinde ifade etmişlerdir. Evrensel değerler (\%8) kapsamında ise vicdanlı özgür bireyler yetiştirmek (\%8) şeklinde ifade etmişlerdir. Sınıf öğretmenleri ilkokulda değer eğitiminin amacını son sırada en az "dini değerler" kapsamında ele almışlardır. Bu bağlamda ise kültüre ve inanca göre yaşamak $(\% 4)$ şeklinde ifadeleri olmuştur.

Bazı sınıf öğretmenlerinin görüşleri aşağıdaki gibidir.

Ö1: Illkokulda değerler eğitiminin amacı çocuğun iyi, ahlakl, toplumun değerlerini bilen ve bunlara saygı duyan bireyler yetiştirmek olduğunu düşünüyorum.

ö2: Çocuğun karakterini her yönden geliştirmek, doğruya yönlendirmek.

ö3: Öğrencinin kendi kültürü ve inancına göre yaşamayı öğrenmelidir.

Ö4: Kişilik sahibi nesiller yetiştirmek.

Ö6: Topluma faydalı birey yetiştirmek için. Doğru davranış kazanmaları için

Ö7: Türk toplumun da birlik beraberlik sağlamak için. Birlikte hareket etme duygusu oluşturmak için. Ortak nokta da bulunup birçok değeri kaybetmemiz için.

ö8: Vatana, millete, ailesine yararl bireyler yetiştirmek. 


\subsection{Değerler eğitiminde ne tür etkinlikler yaparsınız?}

Sınıf öğretmenleri değerler eğitiminde drama, örnek olay, bulmaca, fikra, resim, masal, hikâye, anlatım gibi yöntem ve tekniklerden yararlandıklarını ifade etmişlerdir.

Tablo 3. Değerler eğitiminde yapılan etkinlikler

\begin{tabular}{lcc}
\hline Yapılan Etkinlikler & f & $\mathbf{\%}$ \\
\hline 1. Örnek olay & 8 & 32 \\
2. Drama & 3 & 16 \\
3. Bulmaca & 2 & 12 \\
4. Film & 2 & 8 \\
5. Resim & 2 & 8 \\
6. Öykü & 2 & 8 \\
7. Şiir & 1 & 4 \\
8. Ahlaki ikilem & 1 & 4 \\
9. Fikra & 1 & 4 \\
10. Tiyatro & 1 & 4 \\
11.Pano & 1 & 4 \\
12.Proje & 1 & 4 \\
\hline Toplam & $\mathbf{2 5}$ & $\mathbf{1 0 8}$ \\
\hline
\end{tabular}

Tablo 3 incelendiğinde, öğretmenlerin değerler eğitiminde sırasıyla kullandıkları yöntem ve teknikler: örnek olay (\%32) drama (\%12), bulmaca (\%8), film (\%8) resim (\%8), öykü (\%8), şiir (\%4) ahlaki ikilem (\%4) fikra ( \%4), tiyatro (\%4) pano (\%4) ve proje (\%4) şeklinde açıklamışlardır. Bu tabloda öğretmenlerin değerler eğimini verirken en fazla örnek olayı kullandıkları görülmektedir. Toplam yüzdeliğin \%108 çıkması bir öğretmenin değerler eğitiminde birden fazla etkinliği aynı anda kullanmasından kaynaklıdır.

\subsection{Değerler eğitiminde karşılaştığınız güçlükler nelerdir? Çözüm önerileriniz nelerdir?}

Araştırma kapsamında öğretmenlerin değer eğitiminde karşılaştığı güçlüklerin sıklıkları ve yüzdesi Tablo 4’te verilmiştir.

Tablo 4. Sınıf öğretmenlerinin değerler eğitiminde karşılaştığı güçlükler

\begin{tabular}{lcc}
\hline Karşılaşılan güçlükler & f & \% \\
\hline 1.Yöneltilen soruyu cevapsız bırakanlar & 7 & 28 \\
2.Çocuklar değerlerin adını bilmiyor, bilinçli değil. & 4 & 16 \\
3. Güçlükle karşılaşmadım. & 4 & 16 \\
4. Aile, iş birliği ve çevre ile ilişkiler. & 2 & 8 \\
5. Çevredeki yanlış örnekler. & 1 & 4 \\
6. Çocuğun ailesindeki değer eksikliği. & 1 & 4 \\
7. Velilerin öğrencilerin bencil yetiştirmesi. & 1 & 4 \\
8. Her çocuk için değerin önem ve önceliğinin farklı olması & 1 & 4 \\
9. Kalabalık sınıflar ve fiziki koşullar uygun değil. & 1 & 4 \\
10. Verilen değerin anlaşılmaması. & 1 & 4 \\
11.Soyut konuları somutlaştırmada zorluk. & 1 & 4 \\
12.Değeri davranış haline getirmek çok zor. & 1 & 4 \\
\hline Toplam & $\mathbf{2 5}$ & $\mathbf{1 0 0}$ \\
\hline
\end{tabular}

Tablo 4 incelendiğinde, sınıf öğretmenlerinin değerler eğitiminde sırasıyla karşılaşıtıları güçlükler; çocukların değerlerin adını bilmediklerini (\%16), güçlükle karşılaşmadıklarını (\%16), aile ve çevre ile iş birliğinin zor olduğunu (\%8), çevredeki yanlış örnekler (\%4) çocuğun ailesindeki değer eksikliği (\%4), velilerin öğrencileri bencil yetiştirdiği (\%4) her çocuk için değerin ve önem önceliğinin farklı olması (\%4), kalabalık sınıfların ve fiziki koşulların uygun olmaması (\%4), verilen değerin anlaşılamamış olması (\%4), soyut 
konuların somutlaştırmada zorluk (\%4) ve değeri davranış haline getirmede zorluk (\%4) olarak ifade etmişlerdir. Öğretmenlerin bir kısmı (\%28) “değerler eğitiminde karşılaştığınız güçlükler nelerdir? Çözüm önerileriniz nelerdir?’’ sorusunu yanıtsız bırakmışlardır.

Bazı sınıf öğretmenlerinin görüşleri aşağıdaki gibidir.

Ö1: Değerler ĕgitimini verirken bu değerleri zorla, baskiyla, dayatmayla vermemek gerekiyor. Bu değerleri neden, niçin verdiğimizi çocuklara sorgulatmamı gerekiyor. Bu konuda güçlükler yaşanabilir ama çocuklarla tartışarak sorgulatılarak bu sorun çözülebilir.

\section{Ö2: Her çocuk için her değerin önceliğinin ve öneminin farklı olması}

Ö3: Öğrencinin aile eğitimi ile çelişirse güçlükler yaşanır. Çocuğa empati kavramını vererek çözebiliriz.

Ö4: Çocuklar bazı değerleri bilmiyorlar. Özellikle adını bilmiyorlar. Mesela çocuklar başkalarının düşüncelerin, hislerini anllyorlar ama bunun empati olduğunu bilmiyor. Çocuklar ailede değerler ĕgitimi konusunda eksik kallyor. Öğretime daha çok önem veriliyor. Televizyonun, internetin olumsuz etkileri oluyor. Anne, baba ilgisizliği var. Temel eksik olduğu için biz çoğu yerde eksik kalıyoruz. Paylaşmayı bilmiyorlar bazlları bencil yetişiyorlar.

Ö5: Veliler çocukları putlaştırıyor. Hayatın merkezin de çocuğu alıp bencil yetişstiriyorlar. Çocuk ben duygusu ile yetişiyor. Başka insanların haklarına saygı göstermiyorlar.

\subsubsection{Değerler eğitiminde karşılaştığınız güçlüklere çözüm önerileriniz nelerdir?}

Araştırma kapsamında öğretmenlerin değer eğitiminde karşılaş̧ıkları güçlüklere getirdikleri çözüm önerilerinin sıklıkları ve yüzdesi Tablo 5'te verilmiştir.

Tablo 5. Sınıf öğretmenlerinin değerler eğitiminde karşılaştığı güçlüklere çözüm önerileri

\begin{tabular}{lcc}
\hline Çözüm önerileri & f & \% \\
\hline 1. Yöneltilen soruyu cevapsız & 16 & 64 \\
2.Çocuğa yanlış olanlar hissettirilmeli. & 2 & 8 \\
3.Empati kavramı verilmeli. & 1 & 4 \\
4. Grup çalışması yaptırarak. & 1 & 4 \\
5. Tartı̧̧ma ortamı oluşturulmalı. & 1 & 4 \\
6.Olaylar çocukların seviyelerine indirgenmeli & 1 & 4 \\
7. Okul ve aile işbirliği yapılmalı & 1 & 4 \\
8. Olaylar hayatın içine aktarılarak yapılmalı. & 1 & 4 \\
Toplam & $\mathbf{2 5}$ & $\mathbf{1 0 0}$ \\
\hline
\end{tabular}

Tablo 5 incelendiğinde, sınıf öğretmenleri sırasıyla çözüm önerileri olarak; çocuğa yanlış değerlerin hissettirile bilineceğini savunan (\%8), empati kavramı ile verileceğini savunan (\%4), grup çalışmaları yaptırılarak yapılabileceğini savunan (\%4), tartı̧̧ma ortamı oluşturulmalı $(\% 4)$, olaylar çocukların seviyelerine indirgenmeli (\%4), okul aile iş birliği yapmalı (\%4), olaylar hayatın içine aktarılarak yapılmalı (\%4) ve doğru davranışlar telkin edilmeli (\%4) şeklinde belirmişlerdir.

\subsection{Değerler, ders öğretim programlarında nasıl ele alınmıştır?}

Tablo 6. Değerler, ders öğretim programlarında ele alınış1

\begin{tabular}{lll}
\hline Verilen Cevaplar & f & \% \\
\hline 1. Yöneltilen soruyu cevapsız bırakanlar & 8 & 32 \\
1.Kazanımların içerisinde. & 6 & 24 \\
2.Metinlerin içerisinde. & 3 & 12
\end{tabular}


3.Etkinliklerin içerisinde.

4.Akroştiş şeklinde

5. Konuların içerisinde.

6. Sarmal olarak.

7. Gelişigüzel olarak.

8. Öykü tamamlamalarda.

9. Çok fazla yer almamaktadır.

Toplam

$\begin{array}{rr}2 & 8 \\ 1 & 4 \\ 1 & 4 \\ 1 & 4 \\ 1 & 4 \\ 1 & 4 \\ 1 & 4 \\ \mathbf{2 5} & \mathbf{1 0 0}\end{array}$

Tablo 6 incelendiğinde, verilen değerler eğitiminin programda: sorulan soruyu yanıtsız bırakan (\%32), kazanımların içerisinde (\%24), metinler aracilığıyla (\%12), etkinliklerin içerisinde $(\% 8)$, konuların içinde $(\% 4)$, gelişigüzel $(\% 4)$, sarmal olarak $(\% 4)$, öykü tamamlamalarda (\%4), akrostiş şeklinde şiirlerle (\%4), çok fazla yer almamaktadır (\%4) olarak ifade etmişlerdir. Öğretmenler değerler eğitimin en fazla olarak kazanımların içerisinde yer aldığını belirtmişlerdir.

Bazı sınıf öğretmenlerinin görüşleri aşağıdaki gibidir.

ö1: Bütün derslerde değerler işlenmektedir. Bazı kazanımlarda da değerler eğitimi başlı̆̆ altında değerler yer almaktadır.

Ö2: Kazanımlara yüzeysel olarak sıkıştırılmış ve sayıları az. Sürekliliği ve bir çerçevesi yok.

Ö3: Kazanımlarda yer verilmiştir. 'Örneğin sen olsan nasıl davranırdın'” etkinlikleri gibi.

Ö4: Değer ĕgitimi üzerinden metinler, konular veriliyor. Örnek sorular geçiyor değer farkındalı̆̆ı için.

Ö5: Program da örtük olarak değil direk kazanımlar da geçmeli bence.

Ö6: Çok incelemedim farkında değilim.

Ö7: Kazanımların içinde direk değil örtük olarak geçiyor. Konu başlı̆̆ olabiliyor, metin içinde örneklerle geçiyor. Bütün dersler de değerlere yer veriliyor.

\subsection{Değerler eğitiminde kullandığınız strateji, yöntem ve teknikler nelerdir?}

Tablo 7. Değerler eğitiminde kullanılan stratejiler

\begin{tabular}{llc}
\hline Strateji & f & \% \\
\hline 1. Buluş yoluyla öğretim stratejisi & 2 & 8 \\
Toplam & $\mathbf{2}$ & $\mathbf{8}$ \\
\hline
\end{tabular}

Tablo 7 incelendiğinde, değer eğitiminde kullanılan stratejiler için buluş yoluyla öğretim stratejisi (\%8) olarak ifade edilmiştir. Bu soru öğretmenlere bir bütün halinde sorulduğu için öğretmenlerin sadece 2 tanesi kullandıkları stratejiye değinmişlerdir.

Tablo 8. Değerler eğitiminde kullanılan yöntemler

\begin{tabular}{llc}
\hline Yöntemler & f & \% \\
\hline 1. Örnek olay yöntemi & 11 & 44 \\
2. Anlatım yöntemi & 7 & 28 \\
3.Tartışma & 1 & 8 \\
Toplam & $\mathbf{1 9}$ & $\mathbf{8 0}$ \\
\hline
\end{tabular}

Tablo 8 incelendiğinde, değer eğitiminde kullanılan yöntemler için sirasıyla; örnek olay yöntemi (\%44), anlatım yöntemi (\%28), tartışma yöntemi (\%8) olarak ifade edilmiştir. Bu soru öğretmenlere bir bütün halinde sorulduğu için öğretmenlerin 19 tanesi kullandıkları yöntemlere değinmişlerdir. 
Tablo 9. Değerler eğitiminde kullanılan teknikler

\begin{tabular}{lcc}
\hline Teknikler & f & \% \\
\hline 1.Drama & 14 & 56 \\
2. Soru cevap tekniği & 5 & 20 \\
3.Hikaye yazma & 3 & 12 \\
4. Film izleme & 3 & 12 \\
5. Atasözleri ve deyim & 3 & 12 \\
6. Eğitici oyunları & 2 & 8 \\
7.Altı şapka tekniği & 2 & 8 \\
8. Bulmaca ve bilmece & 2 & 8 \\
9. Kavram haritası & 1 & 8 \\
10. Poster & 1 & 8 \\
11. Beyin firtınası & 1 & 8 \\
Toplam & $\mathbf{3 7}$ & $\mathbf{1 6 0}$ \\
\hline
\end{tabular}

Tablo 9 incelendiğinde sınıf öğretmenlerinin değerler eğitimi yaparken kullandıkları teknikler için en fazla $(\% 56)$ oranında drama tekniğini kullandıkları, $(\% 20)$ soru cevap tekniği, $(\% 12)$ hikâye yazma, $(\% 12)$ film izleme, $(\% 12)$ atasözleri ve deyim, $(\% 8)$ eğitici oyun, $(\% 8)$ altı şapka tekniği, $(\% 8)$ bulmaca ve bilmece, $(\% 8)$ kavram haritası, $(\% 8)$ poster, $(\% 8)$ beyin firtınası olduğunu belirtmişlerdir. Toplam yüzdeliğin \%160 çıkması bir öğretmenin birden fazla tekniği kullandığını göstermektedir.

Bazı sınıf öğretmenlerinin görüşleri aşağıdaki gibidir.

Ö10: Çocuk kendi yazacak, öğrenci merkezli etkinliklerle. Ürün odaklı öğretim proje gibi.

Ö11: Kavram haritası kullaniyorum.

Ö12: Canlandırma, drama günlük yaşam örneklerini kullanıyorum.

Ö13: Atasözlerinden örnek olay, vaka incelemesinden faydalaniyorum.

Ö14: Altı şapka, drama, tiyatro.

Ö15: İkilem örnekleri, örnek olay çalışmaları, dramatizasyon.

Ö16: Drama, film izleme, poster çalışması, hikaye yazma.

\subsection{Değerler eğitiminde kullandığınız değer eğitimi yaklaşımları nelerdir?}

Tablo 10. Değerler eğitiminde kullandığınız değer eğitimi yaklaşımları

\begin{tabular}{lcc}
\hline Yaklaşımlar & f & \% \\
\hline 1. Yöneltilen soruyu cevapsız bırakanlar & 5 & 20 \\
2. Doğrudan öğretim (değer telkini) & 5 & 20 \\
3. Eylemle öğrenme yaklaşımı & 3 & 12 \\
4. Adil topluluk okulları & 3 & 12 \\
5.Yaklaşım bilmiyorum & 3 & 12 \\
6. Karakter eğitimi & 2 & 8 \\
7.Değer açıklama (değer belirginleştirme) & 2 & 8 \\
8.Ahlaki ikilem & 1 & 4 \\
9.Davranış değiştirme & 1 & 4 \\
Toplam & $\mathbf{2 5}$ & $\mathbf{1 0 0}$ \\
\hline
\end{tabular}

Tablo 10 incelendiğinde sınıf öğretmenleri değer eğitiminde kullandıkları yaklaşımları: doğrudan öğretim değer telkini (\%20), eylemle öğrenme yaklaşımı (\%12), adil topluluk okulları (\%12), yaklaşım bilmiyorum (\%12), karakter eğitimi (\%8), değer açıklama/değer belirginleştirme $(\% 8)$, ahlaki ikilem $(\% 4)$, davranış değiştirme $(\% 4)$ olarak belirtmişlerdir. Öğretmenlerin değer eğitimi yaklaşımlarından en fazla değer telkini yaklaşımını kullandığ 
görülmektedir. Değer eğitimi yaklaşımlarından en az ahlaki ikilem ve davranış değiştirme yaklaşımlarını kullandıkları görülmektedir.

Bazı sınıf öğretmenlerinin görüşleri aşağıdaki gibidir.

Ö14: Eylemle öğrenme yaklaşımı.

Ö15: Ahlaki ikilem ve değer açıklama yaklaşımları.

Ö16: Yaparak yaşayarak ögrenme.

Ö17: Doğrudan ögretim yaklaşımını kullanmıyorum. Bütüncül yaklaşımlar ve yaşayarak ögrenme tekniklerinden faydalaniyorum.

Ö18: Karakter eğitimi, doğrudan ögretim, bütüncül

Ö21: Değer açıklama, eylemle öğrenme yaklaşımı, davranış değiştirme gibi yaklaşımları kullanıyorum.

Ö23: Yaklaşımları bilmiyorum.

\subsection{Değerler eğitiminde dersler bazında hangi değerleri hangi derslerde kazandırıyorsunuz?}

Şekil 1. Hayat Bilgisi dersinde verilen değerler

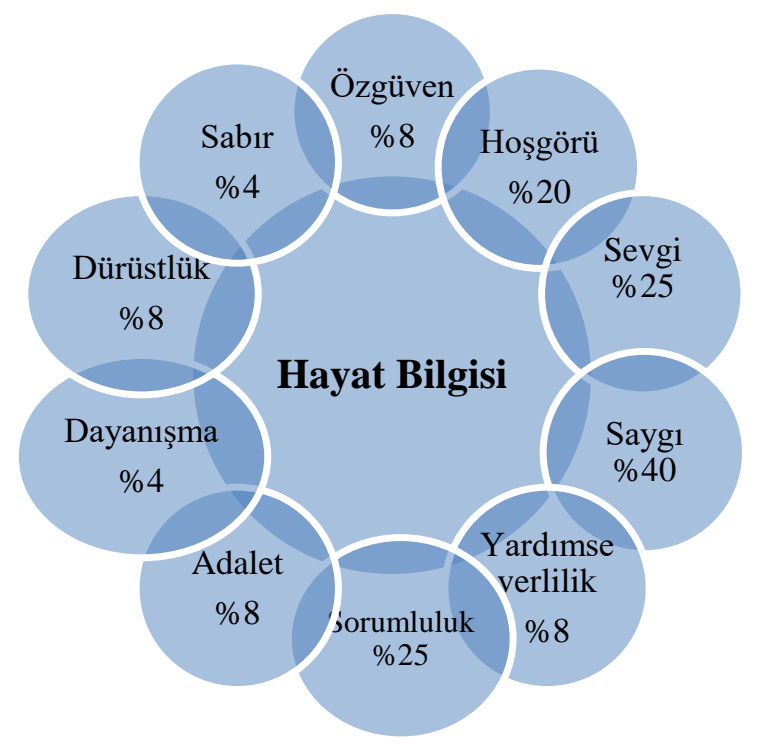

Şekil 1 incelendiğinde, öğretmenler Hayat Bilgisi dersinde sırasıyla; saygı (\%40), sevgi (\%25), sorumluluk (\%25), hoşgörü (\%20), dürüstlük (\%8), özgüven (\%8), yardımseverlik (\%8), adalet $(\% 8)$, sabır (\%4), dayanışma (\%4) değerlerini kazandırdıklarını ifade etmişlerdir. Öğretmenlerin bu derste en fazla sevgi, saygı, sorumluluk ve hoşgörü değerini verdikleri görülmektedir. Toplam yüzdeliğin (\%150) çıkmasının sebebi bir öğretmenin birden fazla değeri aynı anda kullanmasından kaynaklanmaktadır. 
Şekil 2. Türkçe dersimde verilen değerler

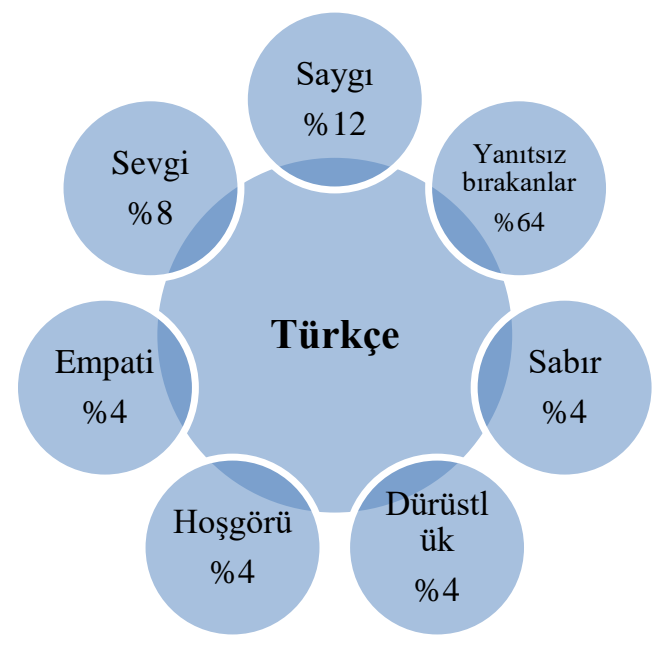

Şekil 2 incelendiğinde öğretmenler Türkçe dersinde sırasıyla; sorulan soruyu yanıtsız bırakanlar (\%64), saygı (\%12), sevgi (\%8), sabır (\%4), dürüstlük (\%4), hoşgörü (\%4), empati (\%4) değerlerini kazandırdıklarını ifade etmişlerdir. Öğretmenlerin bu derste en fazla saygı ve sevgi değerini verdikleri görülmektedir.

Şekil 3. Matematik dersinde verilen değerler

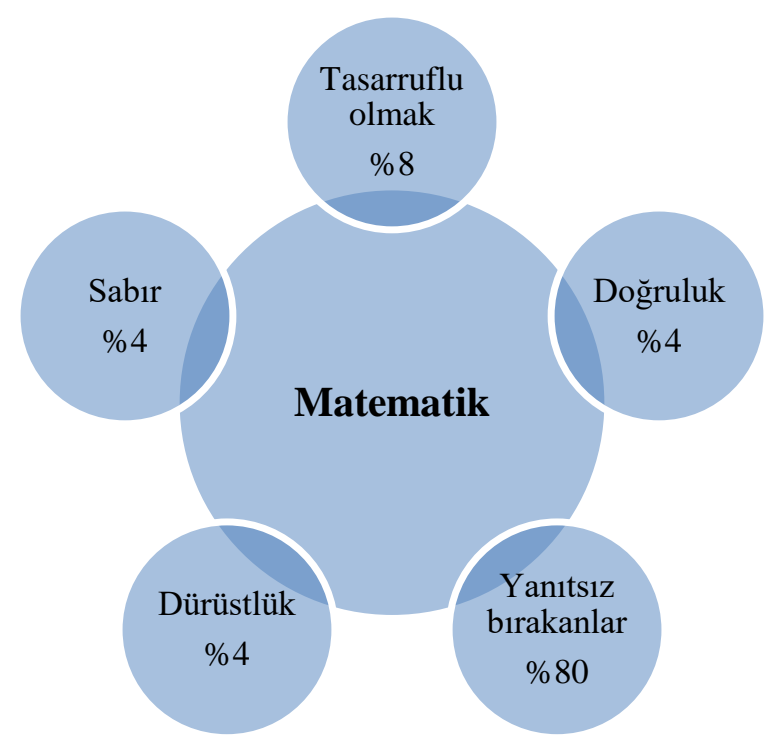

Şekil 3 incelendiğinde öğretmenler matematik dersinde sırasıyla; sorulan soruyu yanıtsız bırakanlar (\%80), tasarruflu olmak (\%8), doğruluk (\%4), dürüstlük (\%4), sabır (\%4) değerlerini kazandırdıklarını ifade etmişlerdir. Öğretmenlerin bu derste en fazla "tasarruflu olma" değerini verdikleri görülmektedir. 
Şekil 4. Sosyal Bilgiler Dersinde verilen değerler

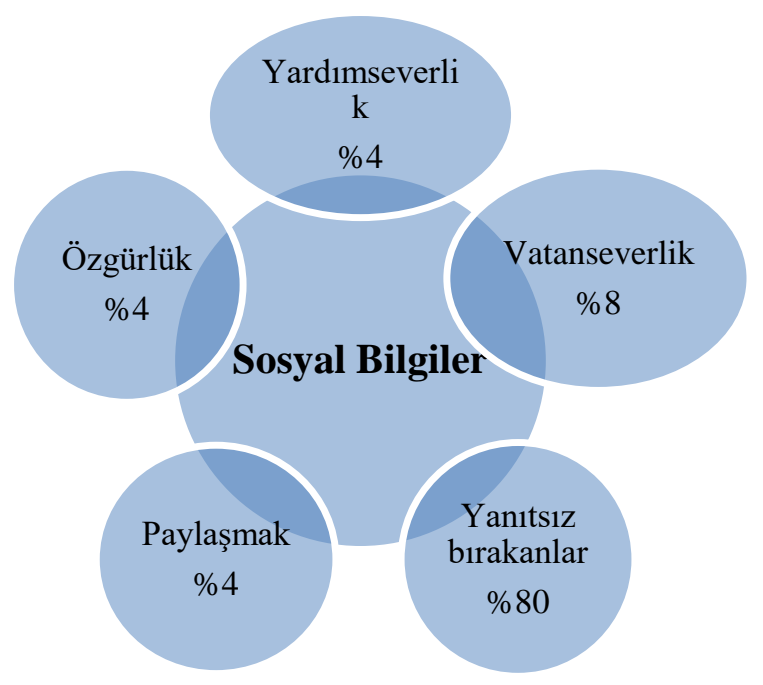

Şekil 4 incelendiğinde öğretmenler Sosyal bilgiler dersinde sırasıyla; sorulan soruyu yanıtsız bırakanlar $(\% 80)$, vatanseverlik (\%8), özgürlük (\%4) paylaşmak $(\% 4)$, yardımseverlik (\%4) değerlerini kazandırdıklarını ifade etmişlerdir. Öğretmenlerin bu derste en fazla vatanseverlik değerini verdikleri görülmektedir.

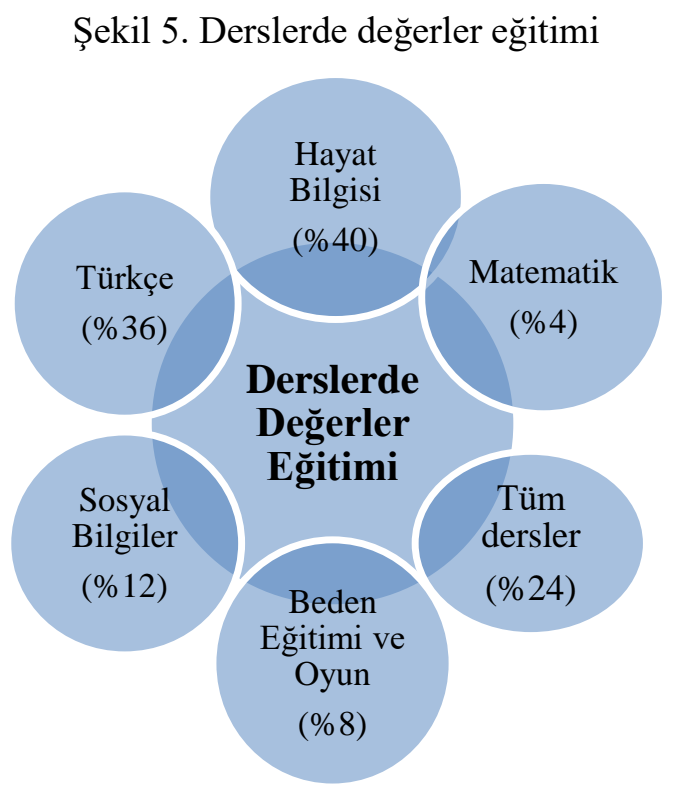

Şekil 5 incelendiğinde öğretmenlerin bir kısmı (\%24) değerleri kazandırırken ders olarak ayırmadıklarını her derste her değeri verebildiklerini ifade etmişlerdir. Değerleri bütüne yaydıklarını, hayat bilgisi dersi ağırlıklı olarak matematik, sosyal bilgiler, Türkçe, Beden Eğitimi ve Oyun derslerinde değerleri kazandırdıklarını ifade etmişlerdir. Öğretmenlerin geri kalan kısmı ise Hayat Bilgisi (\%40), Türkçe (\%36), Sosyal bilgiler (\%12), Beden eğitimi ve oyun (\%8) değerleri bu derslerde kazandırdıklarını ifade etmişlerdir. Toplam yüzdeliğin (\%124) çıkması bir öğretmenin değerler eğitimini birden fazla farklı derste vermesinden kaynaklanmaktadır.

Ö1: Türkçe dersinde: Sevgi, saygı

Hayat bilgisi dersinde: Güven, özgüven, hoşgörü, alçakgönüllülük 
Sosyal bilgiler dersinde: Yardımseverlik, vatan sevgisi, paylaşma

Matematik dersinde: tasarruflu olmak

Ö2: Sevgi, saygl, sorumluluk, yardımseverlik, hoşgörü, özgüven, adalet: Hayat bilgisi, Türkçe: Doğruluk, dürüstlük, sabır: Matematik,

ö4: Iyilikseverlik Türkçe de metinlerde, gelenek göreneklerimiz, vatan sevgisi sosyal bilgilerde.

Ö8: Bütün derslerde değer eğitimine yer verilmesi gerektiğine inaniyorum; fakat ailede kazandirlyorum.

Ö12: Değerleri dersler bazında değil bütüne yayarak, birbiri ile ve dersler içinde veriyorum.

\subsection{MEB değerler eğitimi uygulamaları kapsamında ayın değeri etkinliklerini yeterli buluyor musunuz? Varsa önerileriniz nelerdir?}

Sınıf öğretmenlerinin ayın değeri kapsamında yapılan etkinliklerin yeterliliği konusunda verdikleri cevaplar kapsamında, ayın değeri olarak verilen değerin yeterliği konusunda farklı cevaplara ulaşı1mıştır.

Tablo 11. Sınıf öğretmenlerinin ayın değeri konusunda yeterlilik görüşleri

\begin{tabular}{lcc}
\hline Verilen Cevaplar & f & \% \\
\hline 1.Yeterli bulmuyorum. & 18 & 72 \\
2. Yeterli buluyorum. & 4 & 16 \\
3. Herhangi bir fikrim yok. & 3 & 12 \\
Toplam & $\mathbf{2 5}$ & $\mathbf{1 0 0}$ \\
\hline
\end{tabular}

Tablo 11 incelendiğinde, öğretmenler ayın değeri kapsamında yapılan etkinlikleri çoğunlukla yeterli bulmadıklarını (\%72), çok azı yeterli bulduklarını (\%16), yine çok azının da konu hakkında herhangi bir fikri olmadıklarını (\%12) ifade etmiştir.

Tablo 12. Sınıf öğretmenlerinin ayın değeri konusunda sundukları çözüm önerileri

\begin{tabular}{lcc}
\hline Ç̈züm önerileri & f & \% \\
\hline 1.Yöneltilen soruyu cevapsız bırakanlar & 16 & 64 \\
2. Ders olarak verilmeli & 2 & 8 \\
3.Sadece bir ay değil tüm konuların içinde süreçte olmalı. & 2 & 8 \\
4.Evde değerler eğitimi verilmeli. & 1 & 4 \\
5. Özel bir ders saati ayrılmalı. & 1 & 4 \\
6.Soyut kalmamalı. Sahada olmalı ve değerlerin kalıcılı̆̆ı takip edilmeli & 1 & 4 \\
7. Olaylar hayatın içine aktarılarak yapılmalı. & 1 & 4 \\
8. Doğru davranışlar telkin edilmeli & 1 & 4 \\
Toplam & $\mathbf{2 5}$ & $\mathbf{1 0 0}$ \\
\hline
\end{tabular}

Tablo 12 incelendiğinde, öğretmenlerin ayın değeri konusunda çözüm önerilerini çoğunlukla yanıtsız bıraktıkları (\%64) görülmektedir. Bunun yanında öğretmenler görüşlerini sırasıyla; ders olarak verilebilir (\%8), sadece bir ay değil tüm konuların içinde, süreçte olmalı (\%8), evde değerler eğitimi verilmeli (\%8), özel bir ders saati ayrılmalı (\%4), soyut kalmamalı, sahada olmalı ve değerlerin kalıcılığı takip edilmeli (\%4), olaylar hayatın içine aktarılarak yapılmalı (\%4), doğru davranışlar telkin edilmeli (\%4) olarak ifade etmiştir

\subsection{Değerler eğitiminin zorunlu veya seçmeli ders olarak okutulması konusunda ne düşünüyorsunuz?}

Sınıf öğretmenlerinin değerler eğitimini zorunlu veya seçmeli ders olarak okutulması konusundaki görüşleri üç başlık altında toplanmıştır. Bunlar zorunlu bir ders olarak verilmesi, seçmeli ders olarak çocuğun tercihine bırakılması gerektiği ve değerler eğitiminin ders olarak verilmesinin okulda amacına ulaşmadığı için gerekli görmeyenler şeklindedir. 
Tablo 13. Sınıf öğretmenlerinin değerler eğitiminin ders olarak verilmesi konusunda görüşleri

\begin{tabular}{lcc}
\hline Verilen Cevaplar & f & \% \\
\hline 1.Zorunlu olmalıdır. & 16 & 64 \\
2. Seçmeli ders olarak verilmelidir. & 5 & 20 \\
3. Ders olarak verilmesini yeterli bulmuyorum & 4 & 16 \\
Toplam & $\mathbf{2 5}$ & $\mathbf{1 0 0}$ \\
\hline
\end{tabular}

Tablo 13 incelendiğinde öğretmenler değerler eğitiminin zorunlu bir ders olarak okutulması konusuna çoğunlukla (\%64) katılmış, çok azı seçmeli ders olarak okutulmasını (\%20), yine çok azı da ayrı bir ders olarak verilmesini yeterli bulmadığını (\%16) ifade etmiştir.

Bazı sını öğretmenlerinin görüşleri aşağıdaki gibidir.

ö8: Bir gereklilik olduğunu, mümkünse zorunlu mümkün değilse seçmeli ders olmall.

Ö9: Seçmeli ders olmasından daha verimli olacak, derslerin içinde konulara dağılması daha uygun

Ö10: Illkokulda bir ders saati olarak verilmesi gereklidir.

Ö11: Değerler eğitimi dersi zorunlu olmalıdır.

Ö12: Zorunlu olabilir. Öğrenci dikkat çekilebilir. Kabul görmeyen davranışlar üzerinde durularak yanlışlar giderilebilir.

Ö13: Zorunlu değil de seçmeli okutulabilir.

Ö14: Bence zorunlu olmall, çocuğa davranış değer kazandırmak önemlidir bence.

\section{Sonuç, Tartışma ve Öneriler}

Sınıf öğretmenlerinin ilkokulda değer öncelik sıralaması "bireysel değerler, toplumsal değerler, milli değerler, insani değerler, evrensel değerler ve dini değerler" olduğu görülmektedir. Bu bağlamda "bireysel değerler" kapsamında; kişilik ve karakter sahibi birey yetiştirmek, hayata bireyi hazırlamak ve doğru davranış kazandırmak olarak ifade edilmiştir. Nitekim "bireysel değerler" kapsamında bireyin öz güvenli, öz saygılı ve öz denetimli olması ilkokullarda kazandırılacak değerler eğitiminde ön plana çıkmıştır. İlkokulda değerler eğitiminin amac1 "toplumsal değerler" kapsamında; topluma uyum sağlamak, sosyalleşmeyi sağlamak ve birlikte hareket etmek olarak ifade edilmiştir. Bu anlamda "toplumsal değerler" kapsamında dayanışma, iş birliği ve çalışkanlık ilkokullarda kazandırılacak değerler eğitiminde önemsenmektedir. "milli değerler" kapsamında; kendi kültürünü tanımak ve sahip çıkmak, vatana ve millete faydalı birey olmak, unutulan değerleri geliştirmek, Türk toplumunda birlik ve beraberliği sağlamak ve ortak noktada buluşup birçok değeri kaybetmemek olarak ifade edilmiştir. Bu anlamda "milli değerler" kapsamında vatanseverlik, bağımsızlık, birlik ve kültürünü yaşatmak ilkokullarda kazandırılacak değerler eğitiminde önemli görülmektedir. Öğretmenlerin görüşlerine göre ilkokulda değer eğitiminin amaçlarında "insani değerler" kapsamında doğruya yönlendirmek ve iyi ahlaklı birey yetiştirmek olarak ifade edilmiştir. Nitekim "insani değerler" kapsamında anlayış, hoşgörü, iyilik, duyarlılık, yardımseverlik, paylaşma, empati, merhamet, vefalı olmak değerleridir. "Evrensel değerler" kapsamında ise vicdanlı özgür bireyler yetiştirmek olarak ifade edilmiştir. Bu anlamda "evrensel değerler" kapsamında barış, dürüstlük, özgürlük, saygı, sevgi ve adalet değerleridir. Sınıf öğretmenleri ilkokulda değerler eğitiminin amacını son sırada en az "dini değerler" olarak ifade etmişlerdir. "Dini değerler" kapsamında, kültüre ve inanca göre yaşamak olarak ifade edilmiştir. Bu anlamda "dini değerler" olarak aileye bağlılık, Allah'a inanmak, iffetli olmak, sadelik, tutumlu olmak, sabır, cömertlik, alçakgönüllülük ve güvenilirlik değerleridir. Öğretmenlerin bu görüşlerini Ulusoy ve Arslan (2014)'ın karakter ve değer eğitimi sonrasında iyiyi ve kötüyü birbirinden ayırt edebilen, toplumun temel değerlerini benimsemiş, bunları koruyan ve bunlara 
yön veren, temel hak ve özgürlükler ile insani değerleri benimseyen, insanları ötekileştirmeyen öğrenciler, yani toplumu oluşturan bireyler yetiştirebilir ifadeleri desteklemektedir.

Sınıf öğretmenleri ilkokulda yaptırılacak değer eğitimi etkinliklerini kullanım sıklığına göre: Örnek olay, drama, bulmaca, film, resim, öykü, şiir, ahlaki ikilem, fikra, tiyatro, pano ve proje gibi etkinlikleri sıralamışlardır. Benzer bir çalışma Uzuner (2019) tarafından yapılmış öğretmenlerin değer eğitiminde kullanılan etkinlik örneklerinde video film izletme, hikâye yazma/ hikâye tamamlama, resim çizdirme, görsel okuma şeklinde sıralamışlardır. Batmaz ve Erdoğan (2019) ise, benzer etkinlik örneklerinden afiş, resim, video, drama yaptırma ve somut materyaller kullanma, şiir ve kompozisyon çalışması gibi çalışmaların kullanıldığını belirtmiştir. Söz konusu bulguların araştırma sonuçlarıyla benzerlik gösterdiği görülmektedir.

Sınıf öğretmenleri değerler eğitiminde karşılaştıkları güçlüklerin sıklığına göre: Çocukların değerlerin adını bilmemesi, güçlükle karşılaşmayanlar, yöneltilen soruyu cevapsız bırakanlar, aile ile işbirliği ve çevre ile ilişkiler, çevredeki yanlış rol model ve örnekler, çocuğun ailesinde değer eksikliği, velilerin öğrencileri bencil yetiştirmesi, her çocuk için değerin öneminin ve önceliğinin farklı olması, kalabalık sınıflar, fiziki şartların uygun olmaması, verilen değerin anlaşılamaması, soyut konuları somutlaştırmada yaşanan zorluklar, değeri davranış haline getirmedeki zorluklar olarak tespit edilmiştir. Gür ve diğerlerinin (2015) yapmış olduğu araştırmada, çalışmanın sonucunu desteklemektedir. Araştırma sonucunda değerler eğitiminde öğretmenlerin yarıya yakınının herhangi bir zorluk yaşamadıkları, güçlük yaşayanların da en fazla değerlerin soyut bir konu olmasından dolayı yaş gruplarına uygulamada sıkıntı yaşadıkları belirlenmiştir. Bunun yanı sıra öğrencilerin davranışlarında istenilen değişikliği oluşturmada öğretmenlerin zorluk yaşadıkları ve yaşantılarında yeterli düzeyde değerler eğitimi yer almayan öğrencilerin isteksizlik gösterdikleri görülmektedir. Kurtulmuş, Tösten ve Gündaş'ın (2014) yapmış olduğu araştırmada, değerler eğitimi sürecinde öğretmenlerin karşılaştıkları problemlerden birinin okul olduğu belirtilmektedir. Bu kapsamda, yeterli materyal desteğinin olmaması, öğrencilerin sınıf içi ve okul kararlarına katılmamaları, okul ortamlarının değerler eğitimine uygun olmaması ve yönetimin değerler eğitimine yeterli ilgiyi göstermemesi gibi etkenleri de ifade etmişlerdir. Çengelci, Hancı ve Karaduman'ın (2013) ise, değerler eğitiminde önemle üzerinde durulması gereken konu öğrencilerin değerleri yaparak yaşayarak öğrenmesi için uygulama olanaklarının sağlanması, değer kazanımının okul ve aile tarafından birlikte izlenmesinin önemine dikkat çekmektedir.

Sınıf öğretmenleri verilen değerlerin ders öğretim programlarındaki ele alınış sıklığına göre en fazla (\%32) oranında yöneltilen soruyu cevapsız bırakanlar olmuştur. Ardından kazanımların içerisinde, metinlerin içerisinde, etkinliklerin içerisinde, akrostiş şeklinde, sarmal olarak, gelişigüzel olarak, öykü tamamlamalarda şeklinde cevap vermişlerdir. Ayrıca öğretmenler değerlerin programda "çok fazla yer almadığını" da belirtmişlerdir. Bu bağlamda değerlerin programlarda verilmesi durumunu, öğretmenlerin fikir beyan etmemeleri konuya ilişkin bir düşünceleri olmadığı şeklinde yorumlanabilir. Programlarda verilen değerlerin en çok "kazanımlarda", "ders kitaplarında metinlerin içerisinde" ve "etkinliklerin içerisinde" en çok verilen cevaplardır. Diğer araştırma sonuçlarına bakıldığında, örtük programda değerler eğitiminin kazandırılmasında eğitsel kulüp çalışmaları, belirli gün ve haftalardaki etkinlikler, projeler, sportif ve kültürel etkinliklerin (Aslan, 2019); okuldaki törenlerin ve etkinliklerin örtük program üzerinden değerlerin kazandırılmasında etkili olabileceğini (Akbaş, 2008) belirtmektedirler. Araştırma sonucu ise programda yer verilen değerlerin etkili olabilmesini diğer tüm ders programlarına serpiştirilmesi ve etkinlikler yönüyle destekleyip kısmen benzerlik gösterse de, öğretim programlarında değer kazanımlarına doğrudan yer verilmesinin daha etkili sonuçlar verebileceğini ortaya koymaktadır.

Sınıf öğretmenlerinin değerler eğitiminde kullandıkları strateji, yöntem ve tekniklerin kullanım sıklığına göre: Araştırmanın sonucuna göre: Strateji olarak, buluş yoluyla öğretim stratejisi ön plana çıkarken; Yöntem olarak kullanım sıklığına göre, örnek olay yöntemi, anlatım yöntemi ve tartışma yöntemini kullanmaktadırlar. Teknik olarak ise drama, soru-cevap, hikâye 
yazma, film izleme, atasözleri ve deyim, eğitici oyunlar, altı şapka tekniği, bulmaca ve bilmece, kavram haritası, poster, beyin firtınasını kullanım sıklığına göre sıralamışladır. Yalar ve Yanpar Yelken'in (2011) yapmış oldukları çalışma elde edilen bulguları destekler niteliktedir. Bu çalışmada, değer eğitiminde örnek olay yöntemi, öykü, atasözü ve deyimlerin analizleri gibi etkinliklere daha fazla yer verilmesi gerektiği ifade edilmiştir. Aslan (2019) değerlerin öğrencilere öğretilmesinde ve bunu bireylerin benimseyip yaşantılarında kullandıkları davranışa dönüştürebilmesi için öğrenci merkezli yaklaşım, yöntem ve tekniklerin kullanılması son derece önemlidir. Bu bakımdan; yaratıcı drama, örnek olay, problem çözme, proje, tartışma gibi yöntemler kullanılabilir. Akpınar ve Özdaş (2013) ise, değer eğitiminde öğretmenlerin ağırlıklı olarak anlatma, model olma, drama, beyin firtınası, hikayeleştirme, grup çalışması, örnek olay ve empati kurma tekniğini kullandıklarını belirtmişılerdir.

Sınıf öğretmenlerinin değer eğitiminde kullandıkları yaklaşımların sıklığına göre: Doğrudan değer öğretim yaklaşımı (değer telkini), soruyu yanıtsız bırakanlar, eylemle öğrenme yaklaşımı, adil topluluk okulları yaklaşımı, yaklaşım bilmiyorum, karakter eğitimi yaklaşımı, değer açılama yaklaşımı (belirginleştirme), ahlaki ikilem yaklaşımı, davranış değiştirme yaklaşımı olarak sıralamışlardır. Öğretmenlerin en fazla değer telkini yaklaşımını kullandıkları görülmüş̧ür.

Sınıf öğretmenlerinin değerleri derslerinde kazandırma sıklığına göre: Buna göre bu dersleri; Hayat Bilgisi, Türkçe, Sosyal Bilgiler ve Matematik dersleri olarak belirtmişlerdir. Sınıf öğretmenleri Hayat Bilgisi dersinde kazandırdıkları değerleri: Saygı, sevgi, sorumluluk, hoşgörü, dürüstlük, özgüven, yardımseverlik, adalet, sabır, dayanışma olarak sıralamışlardır. Türkçe dersinde: Saygı, sevgi, sabır, dürüstlük, hoşgörü, empati değerlerini kazandırdıklarını; Sosyal Bilgiler dersinde: Vatanseverlik, özgürlük, paylaşma, yardımseverlik değerlerini kazandırdıklarımı belirtmişlerdir. Matematik dersinde ise: Tasarruflu olma, doğruluk, dürüstlük, sabır değerlerini kazandırdıklarını ifade etmişlerdir. Ayrıca öğretmenlerin bir kısmı bu soruyu yanıtsız bırakmışlardır. Bayır, Çengelci ve Deveci (2016) öğretmen adaylarıyla yaptıkları çalışmada bu görüşlere benzer sonuca ulaşmışlardır. Araştırmanın sonucuna göre, ilkokulda değerler eğitimine yer verilen dersler Hayat Bilgisi, Türkçe, Sosyal Bilgiler ve Matematik dersleridir. Hayat Bilgisi dersi için değerler ve değer eğitimine yönelik çalışmaların (Aktepe ve Yalçınkaya, 2016; Bahçe, 2010; Binbaşıŏlu, 2003; Kabapınar, 2009) olduğu görülmektedir. Bu bağlamda hayat bilgisi dersi, çocuğun yaşamında karşılaştığı sorunlarla ilgili değerlendirme yapmasına, karakter geliştirmesine ve değerlerini oluşturmasına yardımcı olan temel derslerden biridir. Aynı zamanda bu ders, çocukları hayata hazırlamayı ve topuma uyumunu amaçlayan, yaşam boyu öğrenecekleri bilgilere temel olan; temel değerleri kazanması için firsatlar oluşturan bir derstir. Nitekim çocuğun başarılı ve mutlu bir yaşam sürmesine temel oluşturması bakımından bu ders önemli görülmektedir. Sosyal Bilgiler dersinde değerler ve değer eğitimine ilişkin ise, birçok çalışmanın (Balcı ve Yanpar Yelken, 2013; Çengelci, 2010; Kafadar, 2019; Keskin, 2008; Külünkoülu, 2018; Yazar, 2010) yapıldı̆̆ı görülmektedir. Bu çalışmalarda sosyal bilgiler dersinin konuları itibariyle değerler eğitimine son derece müsait olduğu vurgulanmaktadır. Ayrıca materyaller kullanılarak ve etkinlikler yoluyla değerler eğitimi uygulamalarının kalıcılığının arttırılacağı, değer eğitimi yaklaşım, yöntem ve tekniklerinin kullanılmaal sının önemli olduğu ifade edilmiştir. Aynı zamanda Sosyal Bilgiler dersinin, değerlerin teorik anlamda ve eylemsel olarak gerçekleştirilmesine zemin hazırlayan bir ders olma özelliğine işaret edilmiştir.

Değerler eğitimi uygulamaları kapsamında ayın değeri etkinliklerini yeterli buluyor musunuz? Sorusuna öğretmenlerin büyük kısmı yeterli bulmadıklarını ifade etmişlerdir. Ergin ve Karataş'ın (2014) yapmış oldukları çalışmada öğretmenler, müfredatın yoğunluğundan dolayı değerler eğitimine gerekli önemi veremediklerini, değerler eğitiminin formalite olduğunu, faydasının bulunmadığını ifade etmişlerdir. Öğretmenlerin bu görüşleri araştırma sonuçlarıyla örtüşmektedir. Nitekim araştırmanın bu sonucu, değerler eğitiminin okullarda tam anlamıyla veya istenilen seviyede yapılamadığını ortaya koymaktadır. Bu durum okullarda 
değerler eğitiminin bir sorun olarak görüldüğünü ve konunun ciddi olarak ele alınma zaruretini ortaya çıkarmıştır.

Araştırmanın sonucuna göre, sınıf öğretmenleri büyük oranda değerler eğitiminin "zorunlu ders" olarak okutulması gerektiğini ifade etmişlerdir. Aktepe (2014) çalışmasında ailede ve okulda değerlerle ilgili yapılacak programlara ciddi derecede ihtiyaç olduğunu belirtmektedir. $\mathrm{Bu}$ anlamda geliştirilecek aile ve okul programlarının kazanımları doğrultusunda hazırlanacak olan değer uygulamaları ve etkinlikleri, çocukların düzeyine uygun bir şekilde hazırlanır ise, değerler eğitiminin temelleri sağlam atılabilir. Nitekim hazırlanan değerler eğitimi aile ve okul programları "zorunlu veya seçmeli ders" olarak okutulabilir ise değerler eğitimi başarılı bir şekilde gerçekleştirilebilir.

- Okullardaki değerler eğitimi etkinlikleri: İnsani değerler (anlayış, hoşgörü, yardımlaşma, paylaşma, empati, merhamet, vefalı olma); evrensel değerler (barış, dürüstlük, özgürlük, saygı, sevgi, sorumluluk, adalet) ve dini değerler (aileye bağl1lı, Allah'a inanma, iffetli olma, sabır, sadelik, tutumlu olma, cömertlik, alçakgönüllü olma, güvenilir olma) yönüyle arttırılabilir.

- Değerler eğitiminde aile ile iş birliğine gidilmesi ve çevre ile ilişkilere önem verilmesi, çocuğun çevresinde bulunabilecek yanlış rol model ve örneklerden uzak durması sağlanabilir. Velilerin çocuklarının eğitiminde bencillikten ziyade paylaşımcıllı̆ı öğretmesi, her çocuğun önemli olduğu fikrini aşılaması ve empatiyle yetiştirmesi önerilir. Okullarda kalabalık sınıflar yerine daha az öğrencisi olan sınıflara geçilmesi, fiziki şartların daha uygun hale getirilerek yaşamdan örneklerin verilebileceği yaşam mekânların oluşturulması önerilir. Soyut olan değerlerin somutlaştırılmasında önemsenen araç-gereç ve materyallerin kullanılması, değerlerin davranışa dönüşmesine katkıda bulunacağından okullarda yer verilmesi önerilir.

- Sunuş yoluyla öğretim stratejisine ek olarak değerler eğitiminde buluş yoluyla öğretim stratejisi ve araştırma-inceleme yoluyla öğretim stratejilerinin de kullanılması önerilir.

- Örnek olay yöntemi, anlatım yöntemi ve tartışma yöntemleri hali hazırda kullanılan değerler eğitimi yöntemleridir. İlave olarak, iş birliğine dayalı öğrenme yöntemi, bireysel çalışma yöntemi, yaratıcı drama yöntemi, problem çözme yöntemi, proje yöntemi, gezi-gözlem yöntemi, dijital öyküleme yöntemi kullanılabilir.

- Drama, soru-cevap, hikâye yazma, film izleme, atasözleri ve deyimler, eğitici oyunlar, altı şapka tekniği, bulmaca ve bilmeceler, kavram haritası, poster, beyin firtınası tekniklerinin kullanıldığı ifade edilmiştir. İlave olarak istasyon tekniğinden de yararlanılabilir.

- İlkokulda kullanılacak değerler eğitimi etkinliklerinde, disiplinler arası öğretim yaklaşımı ve çoklu zekâ kuramına dayalı öğretim temel alınabilir. Bu bağlamda örnek olay, drama, bulmaca, film, resim, öykü, şiir, ahlaki ikilem oluşturan hikaye ve olaylar, fikra, tiyatro, pano ve proje gibi etkinliklerinden yararlanılabilir. Okullarda değerler eğitimi uygulamalarının gözden geçirilerek, etkinliklerin çeşitlendirilmesi ve zenginleştirilmesi çalışmaları yapılabilir.

- Kullanılan değer eğitimi yaklaşımlarına ilave olarak Değer Analizi, Eylem Yoluyla Öğrenme ve Gözlem Yoluyla Öğrenme Yaklaşımlarının da kullanılması önerilir.

- Okullarda yapılan etkinlik çeşidi arttırılabilir. Örnek olay, drama, bulmacanın yanı sıra daha çok şiir, resim, fikra, öykü, tiyatro, drama, film ve proje çalışmaları yapılabilir.

- İlkokulda değerler eğitimi sadece Hayat Bilgisi, Türkçe, Sosyal Bilgiler ve Matematik derslerinde verilmemektedir. Diğer derslerde de (Görsel Sanatlar, Müzik, Beden Eğitimi ve Oyun, Yabancı Dil, Fen Bilimleri, Din Kültürü ve Ahlak Bilgisi, Trafik Güvenliği, İnsan Hakları, Yurttaşlık ve Demokrasi) değerler eğitimine program içerisinde gereken önemin verilmesi önerilir.

- Sınıf öğretmenlerine yönelik değer eğitimi konusunda bilgilendirici seminerler düzenlenebilir. 


\section{Kaynakça}

Akbaş, O. (2004) Türk milli ĕgitim sisteminin duyuşsal amaçlarının ilköğretim II. kademedeki gerçekleşme derecesinin değerlendirilmesi. (Doktora tezi). Gazi Üniversitesi, Eğitim Bilimleri Enstitüsü, Ankara.

Akbaş, O. (2008) Değerler eğitimi akımlarına genel bir bakış. Değerler Eğitimi Dergisi, 6(16), 9-27.

Aktepe, V. (2014). Ailede değerler eğitimi ve program ihtiyac1. R. Turan ve K. Ulusoy (Ed). Farkl yönleriyle değerler eğitimi kitabı içinde (ss.77-93), Ankara: Pegem Akademi.

Aktepe, V. (2015). Etkinliklerle yardımseverlik değer eğitimi. M. Gündüz (Ed), Değerler eğitimi içinde (ss.175-212), Ankara: Maya Akademi.

Aktepe, V. ve Yalçınkaya, E. (2016). Hayat bilgisi dersinde değer eğitimi ve uygulama. S. Güven, S. Kaymakçı (Ed), Hayat bilgisi ögretimi kitabı içinde (ss.133-177), Ankara: Pegem Akademi Yayıncılık.

Aktepe, V. ve Gündüz, M. (2018). Değerler Eğitimi. V. Aktepe ve A. Uzunöz (Ed), Özel ögretim yöntemleri kitabı içinde (ss.69-105), Ankara: Pegem Akademi Yayıncılık.

Akpınar, B. ve Özdaş F. (2013) İlköğretimde değerler eğitime ilişkin öğretmen görüşleri, Firat Üniversitesi Sosyal Bilimler Dergisi, 23,105-113.

Aslan, S. (2019) Karakter ve değer eğitiminde kullanılan yaklaşım, yöntem ve teknikler. V. Aktepe, M. Gündüz (Ed), Karakter ve değer eğitimi kitabı içinde (ss.157-188). Ankara: Pegem Akademi Yayıncılık.

Bahçe, A. (2010). Hayat bilgisi öğretiminde değerlerin kazandırllma düzeylerinin öğretmen görüşlerine göre değerlendirilmesi. (Yüksek lisans tezi). Selçuk Üniversitesi Eğitim Bilimleri Enstitüsü, Konya.

Balc1, F. A. ve Yanpar Yelken, T. (2013). İlköğretim sosyal bilgiler programında yer alan değerler ve değer eğitimi uygulamaları konusunda öğretmen görüşleri. Ahi Evran Üniversitesi Kırşehir Eğitim Fakültesi Dergisi, 14(1), 195-213.

Baltacı, A. (2018). Nitel araştırmalarda örnekleme yöntemleri ve örnek hacmi sorunsalı üzerine kavramsal bir inceleme. BEÜ SBE Dergisi, 7(1), 231-274

Batmaz, O. ve Erdoğan, T. (2019). Sınıf öğretmenlerinin değerler eğitimine yönelik görüşleri. Kastamonu Education Journal, 27(6), 2681-2692.

Bayır, Ö. Çengelci, T. ve Deveci, H. (2016) Sınıf öğretmeni adaylarına göre ilkokullarda değer eğitimi. Ahi Evran Üniversitesi Kırşehir Eğitim Fakültesi Dergisi, 17(3), 317-339.

Binbaşıŏlu, C. (2003). Hayat bilgisi öğretimi, Ankara: Nobel Yayınc1lık.

Büyüköztürk, Ş., Çakmak, E., Akgün, Ö.E., Çakmak, E., Karadeniz, Ş. ve Demirel, F. (2019). Bilimsel araştırma yöntemleri, Ankara: Pegem Akademi Yayıncılık.

Çelikkaya, T. (2019). Değerin tanımı ve sınıflandırılması. V. Aktepe, M. Gündüz (Ed), Karakter ve değer eğitimi kitabı içinde (ss.66-87), Ankara: Pegem Akademi Yayıncılık.

Çengelci, T. (2010). Illköğretim beşinci sınıf sosyal bilgiler dersinde dĕger ĕgitiminin gerçekleştirilmesine iliş̧kin bir durum çalışması. (Doktora tezi). Anadolu Üniversitesi, Eğitim Bilimleri Enstitüsü.

Çepni, S. (2007). Araştırma ve proje çalışmalarına giriş. (Genişletilmiş 3.Baskı), Trabzon: Celepler Matbaacilık. 
Çınar, F. (2019). Kavramsal çerçeve. V. Aktepe, M. Gündüz (Ed), Karakter ve değer eğitimi kitabı içinde (ss.2-20), Ankara: Pegem Akademi Yayıncılık.

Çengelci, T., Hancı, B. ve Karaduman, H. (2013). Okul ortamında değerler eğitimi konusunda öğretmen ve öğrenci görüşleri. Değerler Eğitimi Dergisi, 25, 33-56.

Ergin, E. ve Karataş, S., (2014). Öğretmenlerin değer eğitimi hakkındaki görüşleri: Bir durum çalışması. Journal of Educational Science, 2(2), 33-45.

Güngör, E. (1998). Değerler Psikolojisi Üzerine Araştırmalar (2. bask1), İstanbul: Ötüken Yayınları.

Gür, Ç., Koçak, N., Şirin, N., Şafak, M. ve Demircan, A. (2015). İlköğretim öğretmenlerinin değerler eğitimine ilişkin görüşleri ve karşılaştıkları güçlüklerin incelenmesi: Ankara örneği. Asya Öğretim Dergisi, 3(1), 78-91.

Kabapınar, Y. (2009). Illköğretimde hayat bilgisi ve sosyal bilgiler öğretimi. Ankara: Maya Akademi.

Kafadar, T. (2019). Türkiye, ABD ve Fransa'nın sosyal bilgiler ögretim programları ve ders kitaplarının değerler eğitimi boyutunda karşılaştırılması. (Doktora tezi). Marmara Üniversitesi Eğitim Bilimleri Enstitüsü, İstanbul.

Keskin, Y. (2008). Türkiye'de sosyal bilgiler ögretim programlarında değerler eğitimi: tarihsel gelişim, 1998 ve 2004 programlarının etkililiğinin araştırılması. (Doktora tezi). Marmara Üniversitesi Eğitim Bilimleri Enstitüsü, İstanbul.

Kurtulmuş, M., Tösten. R. ve Gündaş. A. (2014). İlköğretim 1. kademe öğretmenlerinin değerler eğitimi sürecinde karşılaştıkları sorunlar. Değerler Eğitimi Dergisi, 12(27), 281305.

Külünkoğlu, T. (2018). Ortaokul 5. sinıf sosyal bilgiler dersinde uygulanan değer eğitiminin ögrencilerin dürüstlük değerini kazanma düzeyine etkisi. (Doktora tezi). Giresun Üniversitesi Sosyal Bilimler Enstitüsü, Giresun.

MEB (2010). Talim terbiye kurulu başkanlığ 1 18.milli eğitim şuras1 kararlar1 https://ttkb.meb.gov.tr/meb_iys_dosyalar/2017_09/29170222_18_sura.pdf (Erişim tarihi 07.12.2019).

Montagu, A. (2005). Çocuklarımıza ahlaki değerleri nasıl kazandırabilirsiniz? (R. Öncül Çev.). Ankara: Milli Eğitim Basımevi.

TDK, (2011). Türk Dil Kurumu Türkçe Sözlük. Türk Dil Kurumu yayınları, 11. Baskı, Ankara.

Tillman, D. (2014). 8-14 yaş grubu öğrencileri için yaşayan değerler eğitimi etkinlikleri V. Aktepe (Çev. Ed.). Konya: Eğitim Yayınevi.

Ulusoy, K. (2007). Lise tarih programında yer alan geleneksel ve demokratik değerlere yönelik ögrenci tutumlarının ve görüşlerinin çeşitli değiş̧kenler açısından değerlendirilmesi. (Doktora tezi). Gazi Üniversitesi Eğitim Bilimleri Enstitüsü, Ankara.

Ulusoy, K. ve Arslan, A. (2014). Değerli bir kavram olarak 'değer ve değerler eğitimi'. Farklı Yönleriyle Değerler Eğitimi kitabı içinde (ss.1-14). Ankara: Pegem Akademi Yayıncılık.

Uzunkol, E. (2019). Karakter ve değer eğitimi V. Aktepe, M. Gündüz (Ed), Türkiye'de değerler eğitimi uygulamaları ve araştırmaları kitabı içinde (ss. 263-295). Ankara: Pegem Akademi

Uzun, M. ve Köse, A. (2017). Okul öncesi eğitimde değerler eğitiminin uygulanmasına yönelik öğretmen görüşleri. Bayburt Eğitim Fakültesi Dergisi, 12(23), 305-338.

Uzuner, N. K. (2019). Değerler eğitimine yönelik sınıf öğretmenleri görüşleri. Pesa International Journal of Social Studies, 5(2), 52-53. 
Yalar, T. ve Yanpar Yelken, T. (2011). Değerler eğitiminin geliştirilmesi ile ilgili öğretmen görüşlerinin belirlenmesi ve bir program modülü örneğinin geliştirilmesi. Elektronik Sosyal Bilimler Dergisi. 10(38) 79-88.

Yazar, T. (2010). Illköğretim sosyal bilgiler programında değerler eğitiminin mevcut durumunun belirlenmesi ve ögretmenlere yönelik bir program modülü geliştirme. (Doktora tezi). Mersin Üniversitesi Sosyal Bilimler Enstitüsü, Mersin.

Yeşilyurt, E. (2019). Değerler eğitimine uygunluğu açısından öğretim yöntem tekniklerin incelenmesi: Bir derleme çalışması. Ekev Akademi Dergisi. 77, 121-122.

Yüksel, S. (2005). Örtük programın eğitim fakültesi öğrencilerinin öğretmenlik meslek derslerine yönelik düşüncelerindeki etkisi. Uludağ Üniversitesi Güzel Sanatlar Eğitimi Bölümü Örneği 14. Ulusal Eğitim Bilimleri Kongresinde sunulan sözlü bildiri, Denizli: Pamukkale Üniversitesi.

\section{ETIKK ve BİLIMSEL İLKELER SORUMLULUK BEYANI}

$\mathrm{Bu}$ çalışmanın tüm hazırlanma süreçlerinde etik kurallara ve bilimsel atıf gösterme ilkelerine riayet edildiğini yazar(lar) beyan eder. Aksi bir durumun tespiti halinde Afyon Kocatepe Üniversitesi Sosyal Bilimler Dergisi'nin hiçbir sorumluluğu olmayıp, tüm sorumluluk makale yazarlarına aittir. Yazarlar etik kurul izni gerektiren çalışmalarda, izinle ilgili bilgileri (kurul adı, tarih ve sayı no) yöntem bölümünde ve ayrıca burada belirtmişlerdir.

Kurul adı: Nevşehir Hacı Bektaş Veli Üniversitesi Etik Kurul Kararı

Tarih: 14.05.2020

No: 11 